\title{
Age and growth of Spanish mackerel (Scomberomorus brasiliensis) off the northeastern coast of Brazil
}

\author{
Marcelo Francisco de Nóbrega ${ }^{1,2}$ and Rosangela Paula Lessa ${ }^{1,2}$
}

Age and growth of the Spanish mackerel (Scomberomorus brasiliensis) caught off northeastern Brazil were determined. A total of 831 otoliths were examined - 296 from males ( 12 - $75 \mathrm{~cm} \mathrm{FL),} 212$ from females (11.5 - $72 \mathrm{~cm} \mathrm{FL)} \mathrm{and} 323$ from specimens of undetermined sex (12.4 - $75 \mathrm{~cm} \mathrm{FL).} \mathrm{There} \mathrm{was} \mathrm{a} \mathrm{high} \mathrm{percentage} \mathrm{of} \mathrm{juveniles} \mathrm{in} \mathrm{the} \mathrm{catches,} \mathrm{resulting} \mathrm{mainly} \mathrm{from} \mathrm{the} \mathrm{use} \mathrm{of}$ gillnets. Marginal increment analysis of the otoliths indicated that the shortest distances from the last ring to the edge occurred from November to May, laying down just one ring annually. One to eight rings were found, with specimen lengths ranging from 11.5 to $75.8 \mathrm{~cm}$. The Schunute model was used to determine what model was best fit the data, demonstrating that the specialized von Bertalanffy growth equation is the most appropriate. Curves were established for males $\left(L_{\infty}=79.52 \mathrm{~cm}, K=0.189, t_{0}=-0.384\right.$ year) and females $\left(L_{\infty}=109.18 \mathrm{~cm}, K=0.114, t_{0}=-0.414\right.$ year $)$, which resulted in distinct growth patterns between sexes. Based on the parameters estimated for the sexes separately, males have an approximate longevity of 15.5 years, whereas female longevity is 25.9 years. Specimens between 2 and 6 years of age represented $86 \%(n=5,290)$ of the catch composition, characterizing the species as a catchable stock in the region. The present study updates essential information for assessing the stock of this important resource, for which the last growth studies in the region were carried out approximately thirty years ago.

Foram determinados a idade e o crescimento da serra (Scomberomorus brasiliensis) capturada na região nordeste do Brasil. Um total de 831 otólitos foi examinado, sendo 296 machos (12 - 75 cm FL), 212 fêmeas (11,5 - 72 cm FL) e 323 exemplares com sexo indeterminado (12,4 - $75 \mathrm{~cm}$ FL). Um alto percentual de exemplares jovens foi verificado nas capturas, principalmente pela utilização de redes de emalhar. A análise do incremento marginal nos otólitos indicou que as menores distâncias do último anel a borda ocorrem nos meses de novembro a maio, marcando apenas um anel anualmente. Foram encontrados de 1 a 8 anéis, com comprimentos de 11,5 a 75,8 cm FL. O modelo de Schunute foi utilizado, a fim de verificar qual modelo melhor se ajustava aos dados, demonstrando que a equação de crescimento de von Bertalanffy especializada é a mais indicada. Curvas foram estabelecidas para machos $\left(L_{\infty}=79,52 \mathrm{~cm}, K=0,189, t_{0}=-0,384\right)$ e fêmeas $\left(L_{\infty}=109,18 \mathrm{~cm}, K=0,114\right.$ e $\left.t_{0}=-0,414\right)$, resultando em um padrão distinto de crescimento entre sexos. De acordo com os parâmetros estimados para sexos separadamente, machos apresentam longevidade aproximada de 15,5 anos e fêmeas de 25,9 anos. Exemplares entre 2 e 6 anos de idade representaram 86\% ( $\mathrm{n}=5.290)$ da composição das capturas, caracterizando o estoque capturável da espécie na região. O presente estudo atualiza informações essenciais para avaliação do estado de exploração desse importante recurso, cujo último estudo de crescimento na região foi realizado aproximadamente há 30 anos atrás.

Key words: Otoliths, Scombridae, Neritic species.

\section{Introduction}

The Spanish mackerel (Scomberomorus brasiliensis, Collette, Russo \& Zavalla-Camin, 1978) occurs along the Atlantic coast of Central America, the Caribbean and South America from Belize to the State of Rio Grande do Sul in southern Brazil (Collete \& Nauen, 1983). It is a neritic species that inhabits the epipelagic zone, living mainly on the continental shelf in large schools (especially juveniles). There are currently three recognized species from the genus
Scomberomorus along the Atlantic coast of South America: S. brasiliensis, S. cavalla, and S. regalis.

For a long time, $S$. brasiliensis was confused with $S$. maculatus, from which it differs by having a lower number of vertebrae (47-49) and smaller pelvic fin (3.6-5.9\% of its length) (Collete et al., 1978). In 2003, a total of 6,642 tons of S. brasiliensis were caught in its areas of occurrence (FAO, 2003). It is also an important resource for the artisanal fishing fleet in Brazil, especially in the northeastern region, where 3,071 tons were landed in 2003 (IBAMA, 2003), representing

\footnotetext{
${ }^{1}$ Laboratório de Dinâmica de Populações Marinhas (DIMAR), Departamento de Pesca e Aquicultura, Universidade Federal Rural de Pernambuco (UFRPE). Av. Dom Manuel Medeiros s/n, Dois Irmãos, 52171-900 Recife, PE, Brazil. marnobrega@hotmail.com ${ }^{2}$ Programa de Pós-Graduação em Biologia Animal, Departamento de Zoologia, Universidade Federal de Pernambuco (UFPE). Av. Prof. Moraes Rego 1235, Cidade Universitária, 50670-420 Recife, PE, Brazil.
} 
$46.2 \%$ of all landings of the species in the Caribbean and South America. In Trinidad, S. brasiliensis is considered the most abundant neritic pelagic fish (Julien-Flus, 1988).

Growth studies are important in interpreting population dynamics and the impact of fishery exploitation. Estimates on the age structure of fishery resources allow the construction of age-length keys and the estimation of growth parameters for the application of stock assessment models. This enables comparative studies on growth in different stocks (Pauly, 1987), which allows the identification of indirect evidence of the population structure (Ihssen et al., 1981; Sutter et al., 1991). Most growth studies on Scomberomorus species are based on otolith analysis (Table 1).

In Brazil, age structure estimates for S. brasiliensis and $S$. cavalla based on otolith analysis were carried out in the State of Ceará (northeastern region) between 1960 and 1980 (Nomura, 1967; Ximenes et al., 1978; Ximenes, 1981). More recently, selectivity, growth and stock assessment studies have been carried out in northeastern Brazil (Nóbrega, 2002; Lucena et al., 2004; Nóbrega \& Lessa, 2009a, 2009b).

In northeastern Brazil, S. brasiliensis is exploited especially by the artisanal fleet, between the 10 and $50 \mathrm{~m}$ isobaths, catches undertaken with gillnets predominating (81\%) and, in a lesser proportion, those with surface lines (19\%) (Lessa, 2006). Nóbrega \& Lessa (2009a) assessed the exploitation status of the stock and estimated a mean annual biomass of 4,761 t for a mean yield of 1,437 t/year, indicating that the stock is near its maximal exploitation limit. In the present study, whole otoliths were used to estimate age and analyze the age structure of Scomberomorus brasiliensis caught off northeastern Brazil, thereby contributing essential information (growth parameters) for future assessments of exploitation levels and sustainable catch rates for this important fishery resource in the region.

Table 1. Parameters of von Bertalanffy growth based on otolith analysis for Scomberomorus species carried out in the world ( $L_{\infty}$ in fork length; $\mathrm{M}=$ males; $\mathrm{F}$ = females; $\mathrm{B}=$ both sexes combined).

\begin{tabular}{|c|c|c|c|c|c|c|}
\hline Area & $L_{\infty}(\mathrm{cm})$ & $K$ (/year) & $t_{o}($ year $)$ & Sex & Species & Source \\
\hline NE Brazil & $\begin{array}{l}82.95 \\
96.38 \\
102.6\end{array}$ & $\begin{array}{c}0.2 \\
0.2 \\
0.16\end{array}$ & $\begin{array}{c}-0.4 \\
-0.05 \\
-0.13\end{array}$ & $\begin{array}{l}\text { M } \\
F \\
B\end{array}$ & S. brasiliensis & Nomura, 1967 \\
\hline NE Brazil & $\begin{array}{c}116 \\
137 \\
141.2\end{array}$ & $\begin{array}{l}0.18 \\
0.15 \\
0.14\end{array}$ & $\begin{array}{l}0.22 \\
0.13 \\
0.14\end{array}$ & $\begin{array}{c}\mathrm{M} \\
\mathrm{F} \\
\mathrm{B}\end{array}$ & S. cavalla & Nomura \& Rodríguez, 1967 \\
\hline NE Brazil & $\begin{array}{l}113.3 \\
131.7 \\
124.9\end{array}$ & $\begin{array}{l}0.229 \\
0.164 \\
0.185\end{array}$ & $\begin{array}{c}1.5 \\
2 \\
1.8\end{array}$ & $\begin{array}{c}\mathrm{M} \\
\mathrm{F} \\
\mathrm{B}\end{array}$ & S. cavalla & Ximenes et al., 1978 \\
\hline Trinidad & $\begin{array}{l}71 \\
83\end{array}$ & $\begin{array}{l}0.26 \\
0.23\end{array}$ & & $\begin{array}{c}\mathrm{M} \\
\mathrm{F}\end{array}$ & S. brasiliensis & Sturm, 1978 \\
\hline NE Brazil & $\begin{array}{c}81.6 \\
101.9 \\
106.7\end{array}$ & $\begin{array}{c}0.243 \\
0.176 \\
0.16\end{array}$ & $\begin{array}{l}1.4 \\
1.6 \\
1.6\end{array}$ & $\begin{array}{l}\mathrm{M} \\
\mathrm{F} \\
\mathrm{B}\end{array}$ & S. brasiliensis & Ximenes, 1981 \\
\hline Florida (USA) & $\begin{array}{l}111 \\
142 \\
148\end{array}$ & $\begin{array}{l}0.208 \\
0.136 \\
0.115\end{array}$ & $\begin{array}{l}1.48 \\
1.98 \\
2.36\end{array}$ & $\begin{array}{c}\mathrm{M} \\
\mathrm{F} \\
\mathrm{B}\end{array}$ & S. cavalla & Manooch et al., 1987 \\
\hline Trinidad & $\begin{array}{l}112.3 \\
140.1\end{array}$ & $\begin{array}{l}0.18 \\
0.15\end{array}$ & $\begin{array}{l}-1.79 \\
-1.52\end{array}$ & $\begin{array}{c}\mathrm{M} \\
\mathrm{F}\end{array}$ & S. cavalla & Sturm \& Salter, 1990 \\
\hline Florida (USA) & $\begin{array}{c}53.8 \\
72.3 \\
76\end{array}$ & $\begin{array}{l}0.31 \\
0.24 \\
0.18\end{array}$ & $\begin{array}{c}-2.31 \\
-1.8 \\
-2.44\end{array}$ & $\begin{array}{c}\mathrm{M} \\
\mathrm{F} \\
\mathrm{B}\end{array}$ & S. maculatus & Schmidt et al., 1993 \\
\hline Atlantic ocean (USA) & $\begin{array}{c}96.4 \\
126.7\end{array}$ & $\begin{array}{l}0.262 \\
0.145\end{array}$ & $\begin{array}{l}-1.98 \\
-3.15\end{array}$ & $\begin{array}{c}\mathrm{M} \\
\mathrm{F}\end{array}$ & S. cavalla & DeVries \& Grimes, 1997 \\
\hline E. Gulf of Mexico & $\begin{array}{l}102.6 \\
137.8\end{array}$ & $\begin{array}{l}0.247 \\
0.172\end{array}$ & $\begin{array}{l}-1.84 \\
-1.83\end{array}$ & $\begin{array}{c}\mathrm{M} \\
\mathrm{F}\end{array}$ & S. cavalla & DeVries \& Grimes, 1997 \\
\hline W. Gulf of Mexico & $\begin{array}{l}102.8 \\
134.1\end{array}$ & $\begin{array}{c}0.203 \\
0.15\end{array}$ & $\begin{array}{l}-2.74 \\
-2.69\end{array}$ & $\begin{array}{c}\mathrm{M} \\
\mathrm{F}\end{array}$ & S. cavalla & DeVries \& Grimes, 1997 \\
\hline Queensland (Australia) & $\begin{array}{l}62.8 \\
65.1\end{array}$ & $\begin{array}{l}0.709 \\
0.585\end{array}$ & $\begin{array}{l}-1.262 \\
-1.41\end{array}$ & $\begin{array}{c}\mathrm{M} \\
\mathrm{F}\end{array}$ & S. queenslandicus & Begg \& Sellin, 1998 \\
\hline Queensland (Australia) & $\begin{array}{l}76.8 \\
84.9\end{array}$ & $\begin{array}{l}0.225 \\
0.459\end{array}$ & $\begin{array}{l}-4.329 \\
-1.539\end{array}$ & $\begin{array}{c}\mathrm{M} \\
\mathrm{F}\end{array}$ & S. munroi & Begg \& Sellin, 1998 \\
\hline Queensland (Australia) & $\begin{array}{l}128 \\
155\end{array}$ & $\begin{array}{l}0.25 \\
0.17\end{array}$ & $\begin{array}{l}-1.72 \\
-2.22\end{array}$ & $\begin{array}{c}\mathrm{M} \\
\mathrm{F}\end{array}$ & S. commerson & McPherson, 1992 \\
\hline
\end{tabular}




\section{Material and Methods}

Length (fork length - FL, cm) and weight (TW, g) of the Spanish mackerel were collected daily from the artisanal fleet operating with hand lines and gillnets off northeastern Brazil (Fig. 1) between February 1998 and April 2001. The fishing areas had depths from 4 to $204 \mathrm{~m}$ (mean $=36.3 \mathrm{~m}$; SD $=26.9 \mathrm{~m}$ ), with the distance from shore ranging from 1.37 to $54.42 \mathrm{~km}$ (mean $=15.72 \mathrm{~km}$; SD = 11.4). Potential regression between the FL and TW was calculated for combined sexes.

To determine growth, specimens $(n=1,041)$ were measured and weighed. Sex was determined through a macroscopic analysis of the gonads (Vazzoler, 1996). Sagittal otoliths were removed, washed and dry stored.

The right otolith of each pair was examined whole in vegetable oil on a black background under transmitted light. Otoliths were classified into age groups based on the number of translucent bands. Distances from the nucleus to the edge (otolith radius - OR) and between translucent bands were measured (Fig. 2) with a stereoscopic microscope equipped with ocular micrometer at 10x magnification (1 micrometer unit $=1 \mathrm{~mm}$ ). A single reader analyzed each otolith on different occasions with no knowledge on the size of the individual or the previous bands count. Average percentage error (Beamish \& Fournier, 1981) was used to compare the concordance of age determination between two readings.

Marginal increment analysis was performed to determine the periodicity of ring formation by subtracting the otolith radius (OR) measurement from the last growth ring $\left(r_{n}\right)$. For monthly marginal increment analysis, the sample was divided into juveniles ( $\leq 3$ years) and adults ( $\geq 4$ years) based on the

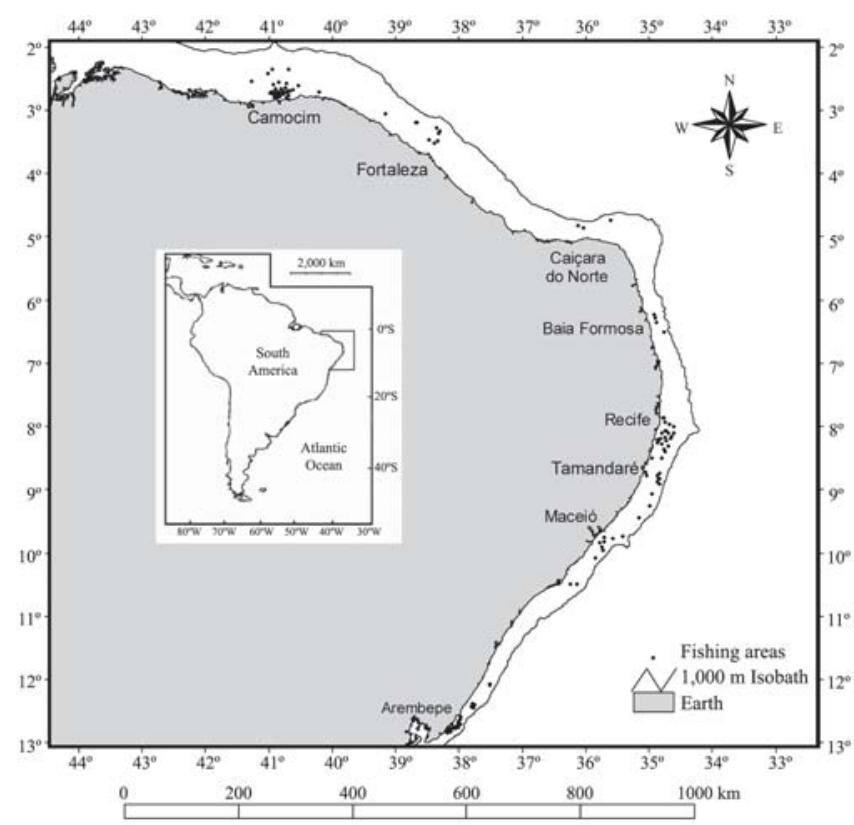

Fig. 1. Sampling locations and fishing areas of Spanish mackerel (Scomberomorus brasiliensis) collected off northeastern Brazil.

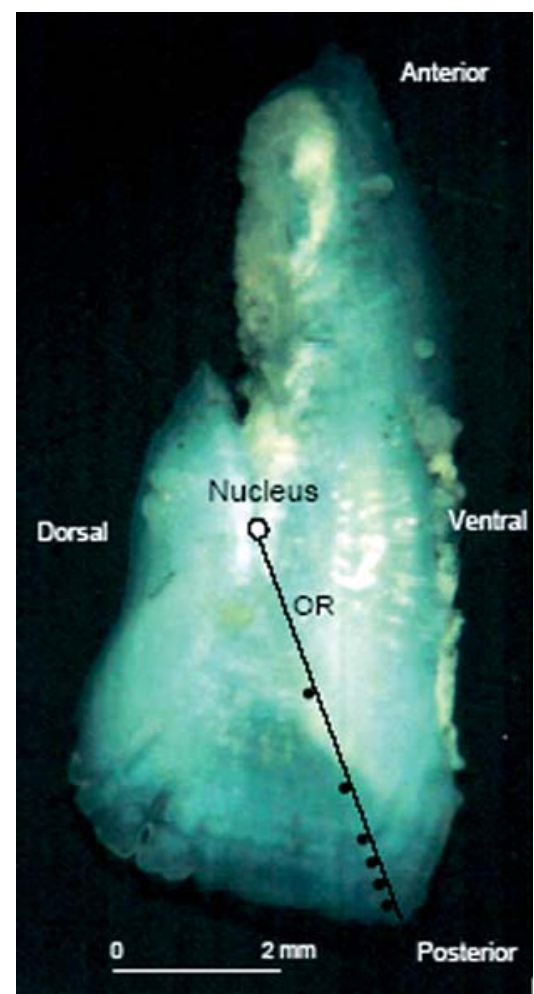

Fig. 2. Characteristics of whole otoliths from Scomberomorus brasiliensis observed under transmitted light for age determination. Female specimen, six years of age, measuring $57 \mathrm{~cm}$ FL (OR = otolith radius; • = translucent bands).

maturity scale proposed by Gesteira \& Mesquita (1976). Analysis of variance (ANOVA) and a post-hoc least significant difference test were used to determine significant differences between months.

Potential regressions between the OR and FL were calculated for males, females and combined sexes. Analysis of covariance was used to compare the correlation between the OR and FL for males and females. Measurements of the distance between the otolith nucleus and the last band were back-calculated using the Monastyrsky equation (1) for the body proportionality hypothesis (BPH) (Francis, 1990):

$$
L_{i}=\left(S_{i} / S_{c}\right)^{b} \cdot L_{c}
$$

in which $L_{i}=$ the back-calculated length at last age; $S_{i}=$ otolith radius at the time of the last band; $S_{c}=$ the otolith radius at capture; $L_{c}=$ the length at capture; and $b=$ the slope coefficient of the relationship between OR and FL (potential relationship for combined sexes).

To determine which growth model best fit the observed and backcalculated lengths of males, females and combined sexes in northeastern Brazil, the growth equation formulated by Schnute (1981) was employed, using the nonlinear least squares method (2). Relative growth rates $z_{1}$ and $z_{2}$ were also 
calculated (3 and 4) (Schnute, 1981):

$$
\begin{aligned}
& L_{t}=\left[y_{1}^{b}+\left(y_{2}^{b}-y_{1}^{b}\right) \frac{1-e^{-a\left(t-\tau_{1}\right)}}{1-e^{-a\left(\tau_{2}-\tau_{1}\right)}}\right]^{1 / b} \\
& z_{1}=\frac{\left(\left(y_{2}^{b}-y_{1}^{b}\right) / b\right) \cdot e^{-a \tau_{1}}}{\left(\left(e^{-a \tau_{2}}-e^{-a \tau_{1}}\right) / a\right) \cdot y_{1}^{b}} \\
& z_{2}=\frac{\left(\left(y_{2}^{b}-y_{1}^{b}\right) / b\right) \cdot e^{-a \tau_{2}}}{\left(\left(e^{-a \tau_{2}}-e^{-a \tau_{1}}\right) / a\right) \cdot y_{2}^{b}}
\end{aligned}
$$

where $L_{\mathrm{t}}$ is predicted length at age $t ; \tau_{1}=$ first specified age; $\tau_{2}$ = second specified age; $a=$ constant relative rate of relative growth rate; $b=$ incremental relative rate of relative growth rate; $y_{1}=$ size at age $\tau_{1} ; y_{2}=$ size at age $\tau_{2} ; z_{1}=$ relative growth rate at age $\tau_{1} ; z_{2}=$ relative growth rate at age $\tau_{2}$.

Growth parameters were calculated for males, females and combined sexes using the specialized von Bertalanffy equation with $\mathrm{p}=1 / \mathrm{b}(5)$, with individual observed lengths and lengths backcalculated to the last band of each specimen:

$$
L_{t}=L_{\infty}\left(1-e^{-k\left(t-t_{0}\right)}\right)^{1 / b}
$$

where $L_{\mathrm{t}}$ is predicted length at age $t ; L_{\infty}=$ mean asymptotic fork length; $K=$ growth rate constant; $t_{0}=$ the age when length is theoretically zero; $b=$ incremental relative rate of relative growth rate.

Variability in the estimated growth parameters for males, females and combined sexes was determined using 95\% confidence intervals generated from normal bivariate distribution for the $L_{\infty}$ and $K$ parameters, conditioned to the estimated $t_{0}$ value (conditional distribution) using the parameter vector, its covariance matrix and a function that provides the p density contours for a normal bi-dimensional variable (Kimura, 1980; Cerrato, 1990). To compare the estimated growth parameters for males and females, the Hotelling $\mathrm{T}^{2}$ test was employed and 95\% confidence intervals were constructed for the difference between the $L_{\infty}, K, \mathrm{t}_{0}$ growth parameter vectors in order to graphically represent the test according to the following hypotheses (Cerrato, 1990):

$$
\theta_{\text {female }}=\left(\begin{array}{c}
L_{\infty} \\
K
\end{array}\right) \quad \text { and } \quad \theta_{\text {male }}=\left(\begin{array}{c}
L_{\infty} \\
K
\end{array}\right)
$$

$$
\begin{aligned}
& \delta=\theta_{\text {female }}-\theta_{\text {male }} \\
& H_{0}=\delta=0 \\
& H_{1}=\delta \neq 0
\end{aligned}
$$

An age-length key was constructed from the entire sample of otoliths ( $n=831$ ), thereby establishing the age structure of the overall sample $(n=6,148)$. To estimate the longevity of the Spanish mackerel in northeastern Brazil was used the equacion (6) proposed by Taylor (1958):

$$
\text { Age }_{\max }=t_{0}+2.996 / K
$$

where $K=$ growth rate constant; $t_{0}=$ the age when length is theoretically zero.

\section{Results}

The size structure of the overall sample ranged from 9.5 to $96 \mathrm{~cm}$ (mean $=46.7 \mathrm{~cm}$; SD $=12.33 \mathrm{~cm})$ (Fig. 3a). Gillnets caught individuals ranging from 9.5 to $76 \mathrm{~cm} \mathrm{FL}$ (mean $=43.7$ $\mathrm{cm}$; SD $=10.99 \mathrm{~cm}$ ), whereas hand lines caught individuals ranging from 32.1 to $96 \mathrm{~cm} \mathrm{FL}$ (mean $=58.3 \mathrm{~cm} ; \mathrm{SD}=15.58 \mathrm{~cm}$ ). Approximately $60 \%$ and $29 \%$ of catches carried out by gillnets and hand lines are immature specimens, respectively.

There was no significant difference in lengths between males and females (ANOVA, $\mathrm{p}=0.26$ ); however, females had a greater maximum length $(86.5 \mathrm{~cm})$ than males $(76.5 \mathrm{~cm})$ (Fig. $3 \mathrm{~b})$. The weight of the specimens ranged from 12 to 7,640 g (mean $=912 \mathrm{~g} ; \mathrm{SD}=777 \mathrm{~g}$ ). The potential model showed good fit to the regression between the FL and TW (Fig. 3c).

Among the total number of otoliths examined ( $\mathrm{n}=1,041)$, $79.8 \%$ were used - 296 from males $(12-75 \mathrm{~cm}$ ), 212 from females $(11.5-72 \mathrm{~cm})$ and 323 from specimens of undetermined sex $(12.4-75 \mathrm{~cm})$. The average percentage error (APE) between readings ranged from $0 \%$ to $15.98 \%$ of 0 to 8 bands, whereas the overall sample had an APE of $12.6 \%$. The coefficient of variation $(\mathrm{CV})$ between the two readings was $11.88 \%$. The number of translucent bands ranged from 0 to 8 in the 831 specimens, with sizes between 11.5 and $75 \mathrm{~cm}$ FL.

There was a similar pattern for juveniles and adults in marginal increment averages from the last growth ring in relation to the otolith radius, resulting in significantly lower values (ANOVA, $\mathrm{p}<0.001$ ) between November and February (Fig. 4a) for juveniles and statistically significant differences between the period from November to May and the period from June to September (Post-hoc, p < 0.05). In adult specimens, significantly lower average marginal increment values (ANOVA, $\mathrm{p}<0.001$ ) were found between November and May (Fig. 4b) and there was a statistically significant difference between the period spanning from November to June and the period spanning from July to October (Posthoc, $\mathrm{p}<0.05$ ). Thus, an annual growth band deposition pattern was considered.

The potential model showed reasonably fit to the regression between the OR and FL for males (Fig. 5a), females (Fig. 5b) and combined sexes (Fig. 5c). There were no significant differences (ANCOVA, $\mathrm{p}=0.39$ ) in relations between the OR and FL by sex. Mean observed and backcalculated lengths for the ages exhibited similarities (Fig. 6 ), indicating that the bands interpreted on the otoliths may 

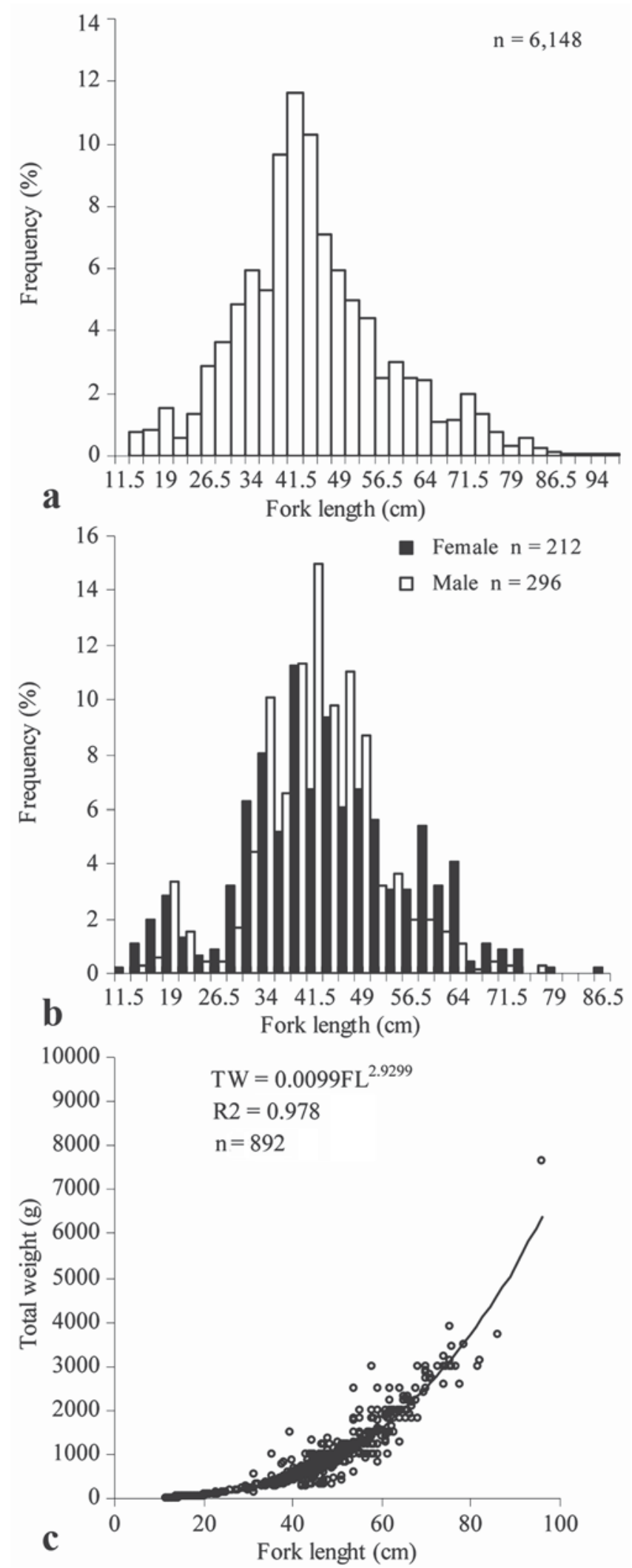

Fig. 3. Length frequency distribution for overall sample (a); Frequency distribution of male and female lengths (b); Relationship between FL and TW (combined sexes) showing adjusted potential model (c) of Spanish mackerel off northeastern Brazil. be used to estimate growth and establish the age structure of the $S$. brasiliensis caught off northeastern Brazil. Absolute ages were calculated considering the month of January as that in which the species changes age.

The growth model proposed by Schnute (1981) estimated $a>0$ and $b \geq 1$ for both sexes separately and combined (Table 2 ), indicating the specialized von Bertalanffy with $p=1 / b$ to be the best growth model for the species. The growth rates $\left(z_{1}, z_{2}\right)$ for $\tau_{1}$ and $\tau_{2}$ demonstrated considerable variation, indicating extremely high growth at the ages established for $\tau_{1}$ and very low growth for older specimens $\left(\tau_{2}\right)$, with $a$ being an estimate of the constant relative growth rate (Table 2).

The growth curves established for separate and combined sexes provided residuals that fit reasonably well to normal distribution (KS, $\mathrm{p}=0.16$ ). Curves from observed and backcalculated data resulted in similar coefficients of determination and standard error for the estimated parameters in both the Schnute model (Table 2) and the von Bertalanffy equation (Table 3). Thus, the estimates obtained
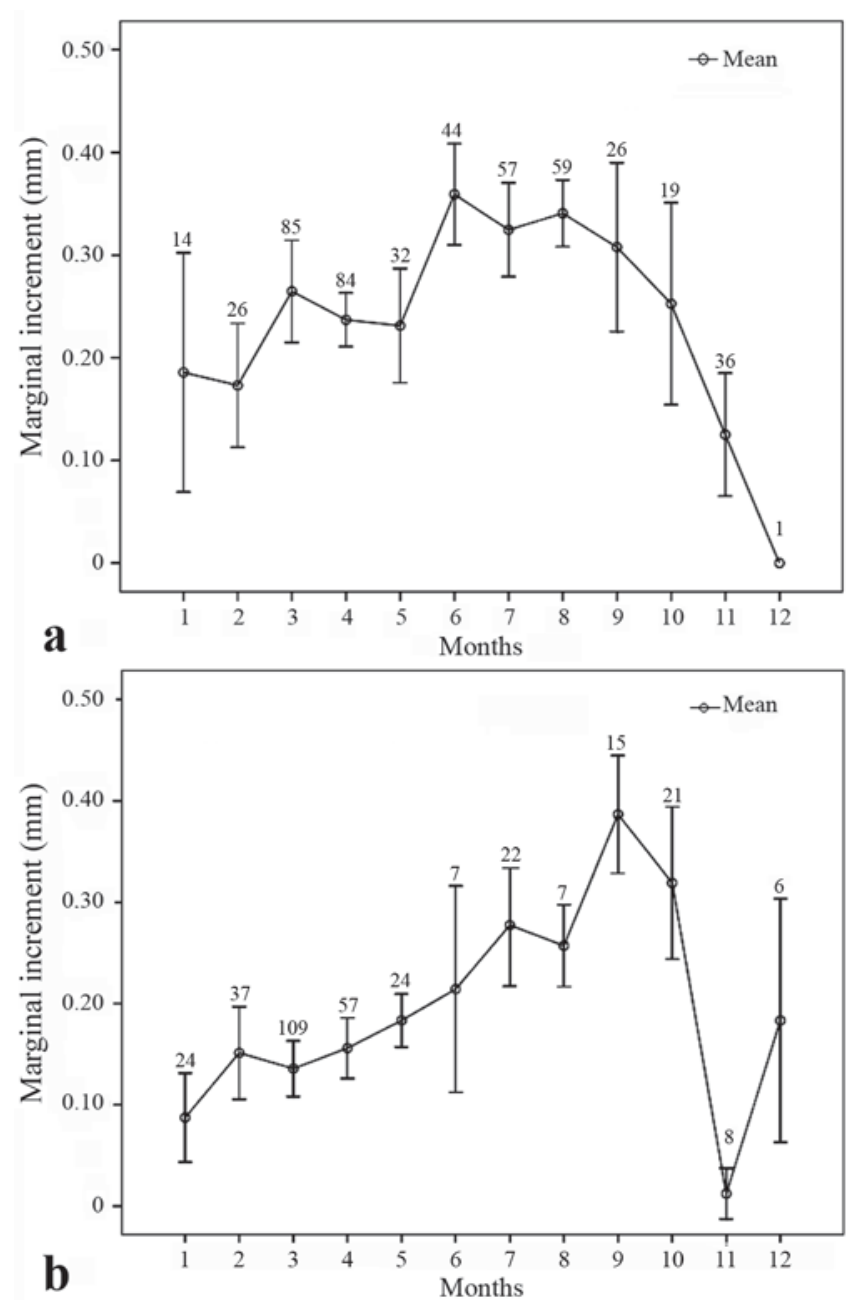

Fig. 4. Marginal increment with mean and 95\% confidence intervals for young specimens (a) and for adults (b) of Scomberomorus brasiliensis in the northeastern Brazil. 

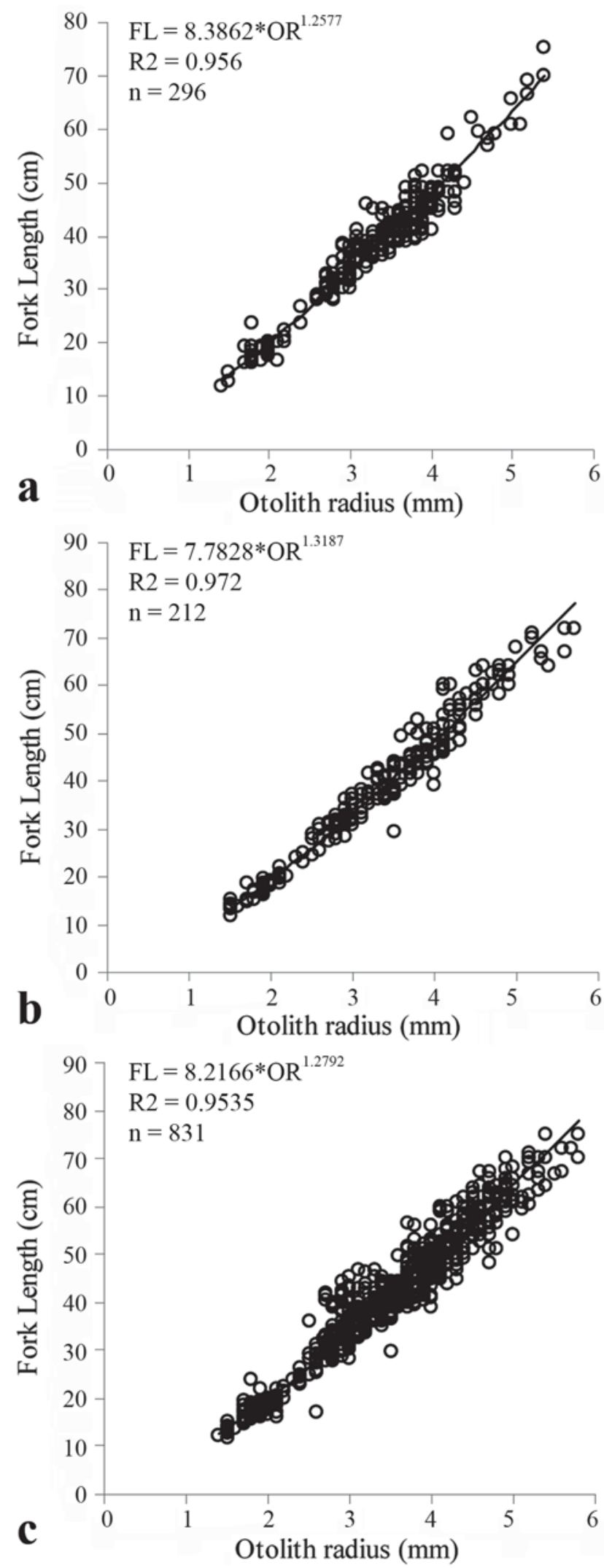

Fig. 5. Relationship between OR and FL for males (a), females (b) and combined sexes (c), showing adjusted potential model for Scomberomorus brasiliensis collected off northeastern Brazil.

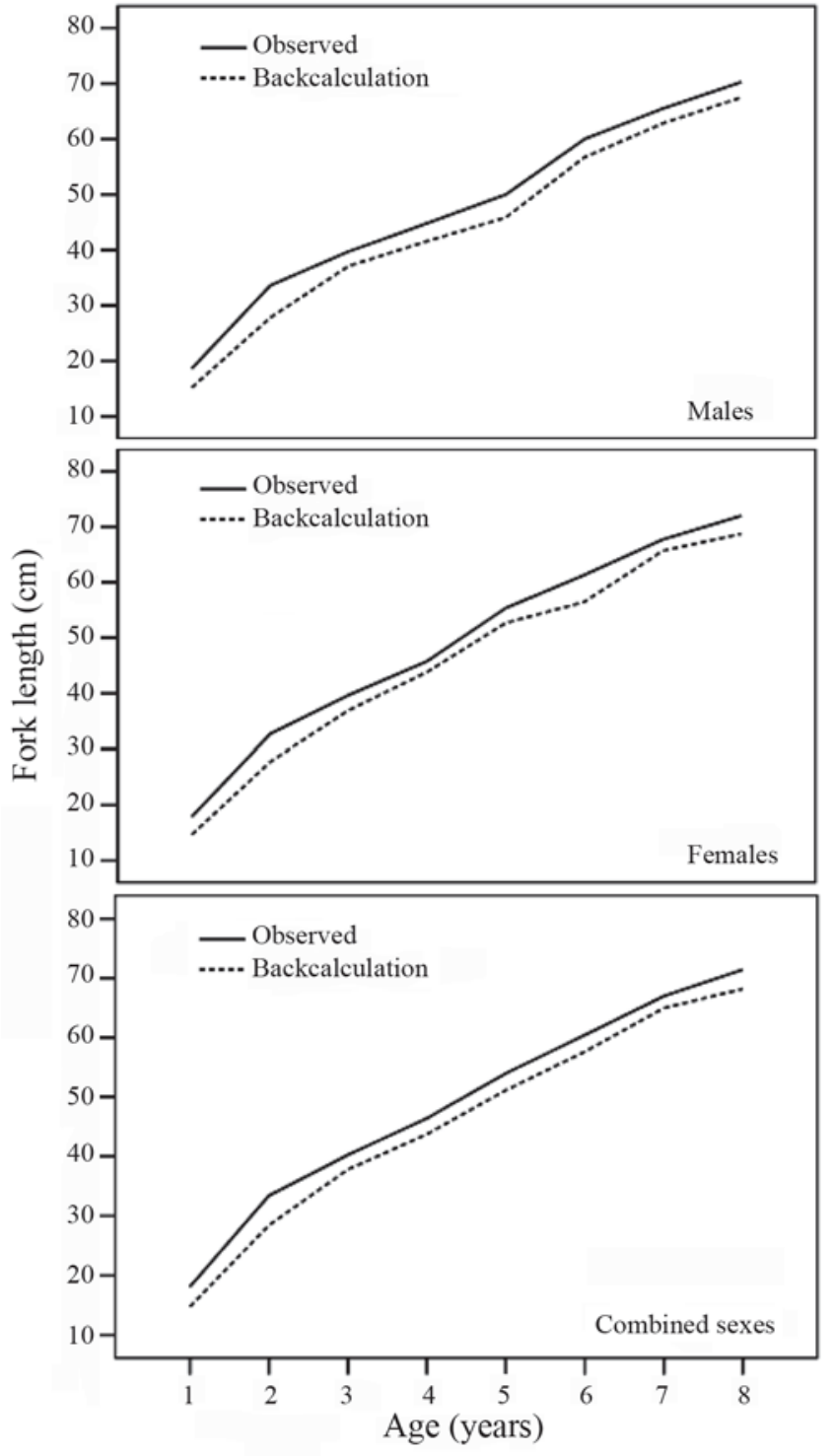

Fig. 6. Mean observed and backcalculated lengths of Scomberomorus brasiliensis at different catch ages for males, females and combined sexes in the northeastern Brazil.

for the observed data were chosen as those that best represent the growth of $S$. brasiliensis in waters off northeastern Brazil.

The established growth parameters indicate that males have a higher growth rate than females and achieve a lower $L_{\infty}$ (Fig. 7). The confidence interval for the $K$ and $L_{\infty}$ parameters conditioned to the $t_{0}$ value (conditional distribution) provided a 95\% likelihood between $L_{\infty}$ values from 87.76 to $130 \mathrm{~cm}$ and $K$ values from 0.085 to 0.143 year $^{-1}$ for females; $L_{\infty}$ from 68.59 to $90.44 \mathrm{~cm}$ and $K$ from 0.152 to 0.226 year $^{-1}$ for males (Fig. 8); $L_{\infty}$ from 87.4 to $101.8 \mathrm{~cm}$ and $K$ from 0.141 to 0.173 year $^{-1}$ for combined sexes.

In the comparison of female and male growth parameters using the Hotelling $T^{2}$ test, significant differences were found 
Table 2. Growth parameters calculated from observed lengths (OL) and back-calculated (BC) lengths, using Schnute model (1981). $\tau_{1}=$ first specified age; $\tau_{2}=$ second specified age; $a=$ constant relative rate of relative growth rate; $b=$ incremental relative rate of relative growth rate; $y_{1}=$ size at age $\tau_{1} ; y_{2}=$ size at age $\tau_{2} ; z_{1}=$ relative growth rate at age $\tau_{1}$; $z_{2}=$ relative growth rate at age $\tau_{2}$ (SE - standard error; $r^{2}$ - coefficient of determination).

\begin{tabular}{|c|c|c|c|c|c|c|c|c|c|c|c|c|c|c|}
\hline Sex & $\mathrm{n}$ & $\tau_{1}$ & $\overline{\tau_{2}}$ & $\overline{y_{1}}$ & SE & $y_{2}$ & SE & $\mathrm{a}$ & SE & $\mathrm{b}$ & SE & $\overline{z_{1}}$ & $\overline{z_{2}}$ & $\mathrm{r}^{2}$ \\
\hline Male & 296 & 1.25 & 8.08 & 20.02 & 0.516 & 59.09 & 0.827 & 0.189 & 0.067 & 1.017 & 0.014 & 0.503 & 0.046 & 0.825 \\
\hline Female & 212 & 1 & 8.08 & 18.47 & 0.594 & 82.27 & 0.300 & 0.114 & 0.020 & 0.956 & 0.004 & .256 & 0.027 & 0.909 \\
\hline Combined & 831 & 0.92 & 8.17 & 15.24 & 0.379 & 70.56 & 0.318 & 0.15 & 0.014 & 0.993 & 0.003 & 0.511 & 0.038 & 0.825 \\
\hline Male & 296 & 1 & 8 & 17.62 & 0.379 & 67.39 & 0.680 & 0.195 & 0.059 & 0.971 & 0.015 & 0.721 & 0.050 & 0.858 \\
\hline Female & 212 & 1 & 8 & 15.26 & 0.409 & 67.2 & 0.350 & 0.165 & 0.026 & 1.001 & 0.007 & 0.560 & 0.040 & 0.926 \\
\hline Combined & 831 & 1 & 8 & 16.92 & 0.257 & 75.81 & 0.276 & 0.184 & 0.016 & 0.958 & 0.004 & 0.674 & 0.044 & 0.905 \\
\hline
\end{tabular}

Table 3. Von Bertalanffy growth parameters calculated from observed lengths (OL) and back-calculated (BC) lengths of Spanish mackerel collected off northeastern Brazil (SE - standard error; $r^{2}$ - coefficient of determination).

\begin{tabular}{clcccccccc}
\hline Methods & \multicolumn{1}{c}{ Sex } & $\mathrm{n}$ & $L_{\infty}(\mathrm{cm})$ & $S E$ & $K(/$ year $)$ & $S E$ & $t_{\mathrm{o}}$ (year) & $S E$ & $r^{2}$ \\
\hline \multirow{2}{*}{ OL } & Male & 296 & 79.52 & 6.41 & 0.189 & 0.03 & -0.384 & 0.162 & 0.825 \\
& Female & 212 & 109.18 & 14.30 & 0.114 & 0.024 & -0.414 & 0.155 & 0.909 \\
& combined & 831 & 95.7 & 4.93 & 0.15 & 0.014 & -0.212 & 0.074 & 0.895 \\
\cline { 2 - 9 } BC & Male & 296 & 74.56 & 5.54 & 0.195 & 0.027 & -0.226 & 0.111 & 0.858 \\
& Female & 212 & 91.497 & 7.09 & 0.165 & 0.023 & -0.108 & 0.099 & 0.926 \\
& combined & 831 & 81.521 & 3.20 & 0.184 & 0.013 & -0.106 & 0.056 & 0.905 \\
\hline
\end{tabular}

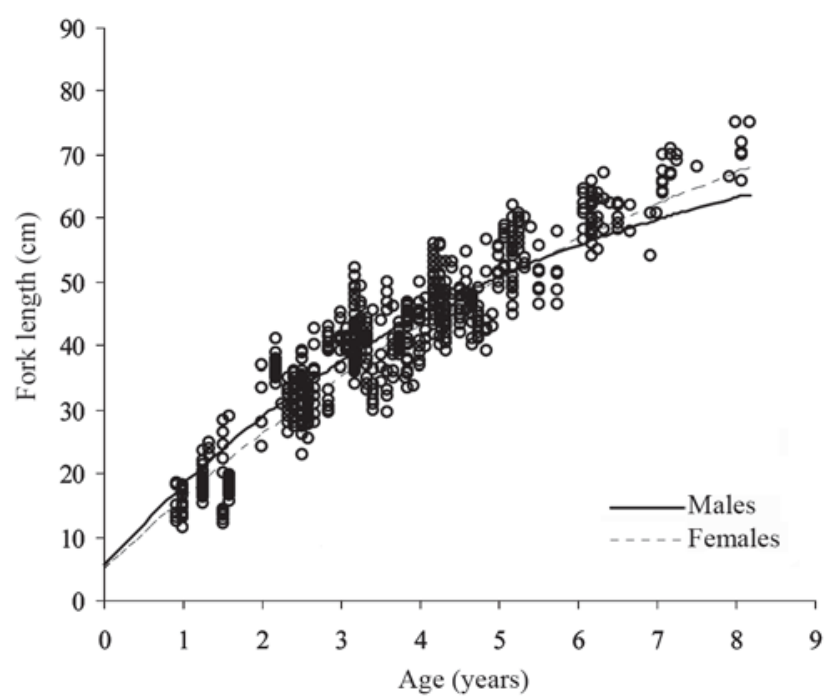

Fig. 7. Growth curves using observed lengths for Scomberomorus brasiliensis collected off northeastern Brazil.

$\left(T^{2}=751.012 ; F=374.76 ;\right.$ d.f. $\left.=3.013 ; \mathrm{p}<0.001\right)$. This result is graphically illustrated in Fig. 9 , in which the $H_{0}$ point $(\delta=0)$ is not contained within the $95 \%$ confidence interval created for the difference between female and male growth parameters $(\delta \neq 0)$.

Employing the age-length key for the sample used in the growth study, the age structure was calculated for the overall sample $(n=6,148)$. Individuals between two and six years of age represented $86 \%$ of the total (Fig. 10). Based on the parameters estimated for the sexes separately, males have an approximate longevity of 15.5 years, whereas female longevity is 25.9 years.

\section{Discussion}

Whole otoliths of S. brasiliensis were used in the present study, as they offered good visibility of the bands (Fig. 2) and an acceptable average percent error (12.6\%) between readings (Campana, 2001). This APE indicates that the aging protocol adopted is replicable. Whole otoliths have been used by a number of authors to estimate the age of species from the genus Scomberomorus (Nomura, 1967; Beaumariage, 1973; Johnson et al., 1983; Manooch et al., 1987; Collins et al., 1989; DeVries \& Grimes, 1997; Begg \& Sellin, 1998) due to the easy preparation and visualization of the growth bands (Manooch et al., 1987).

A pattern of a greater frequency of translucent bands on the edge of otoliths was observed between November and May, thereby evidencing annual band formation. This result is essential for the estimation of the age of $S$. brasiliensis in waters off northeastern Brazil, as the confirmation of the periodicity of growth band deposition is a basic requirement for the study of growth using hard structures (Casselman, 1983). Ximenes (1981) found similar results in northeastern Brazil, with reductions in the translucent margins occurring in the otoliths from December to March, coinciding with the period of smaller marginal increments observed in the otoliths of adult specimens in the present study. Nomura (1967) either found a greater frequency of translucent bands on the edge of otoliths from $S$. brasiliensis in the State of Ceará (northeastern Brazil) from January to April.

Reproduction occurs between September and March along the coast of the State of Ceará (Gesteira \& Mesquita, 1976) and coincides with the change in age, which occurs from November to March. Seasonal marks on hard structures are generally associated to temperature in regions at high 


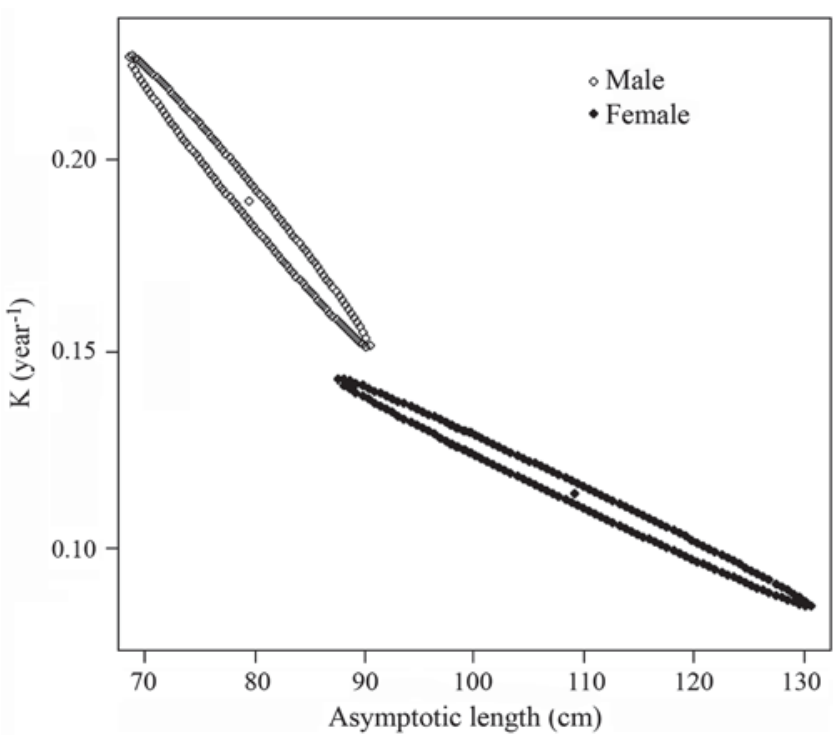

Fig. 8. Cross sections of approximate $95 \%$ confidence regions around least squares estimates $\left(L_{\infty}, K\right)$ for growth parameters of males and females of Scomberomorus brasiliensis collected off northeastern Brazil.

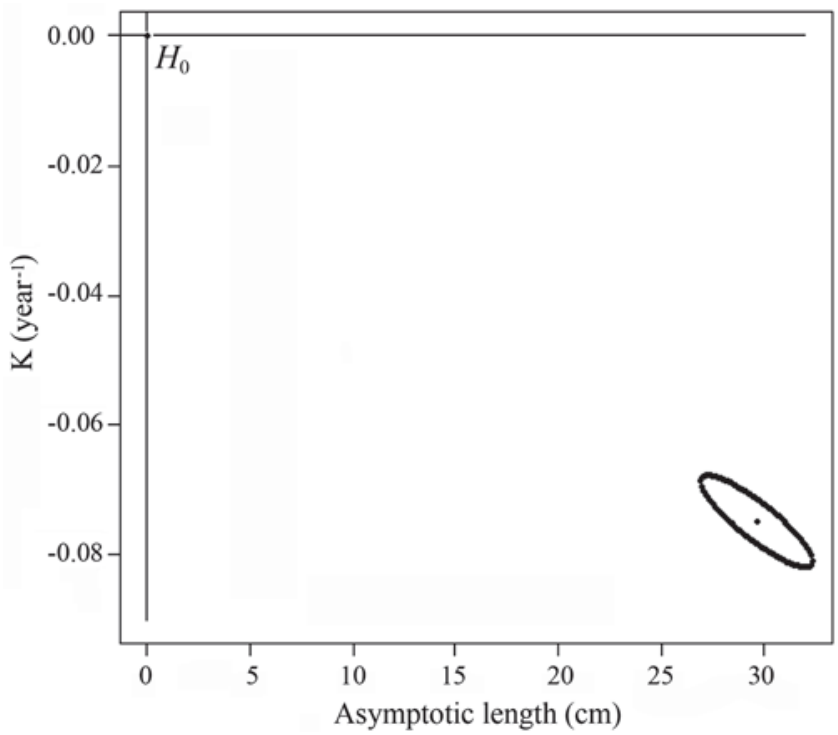

Fig. 9. Cross section of approximate 95\% confidence intervals calculated for the difference between the vectors of the growth parameters $\left(L_{\infty}, K\right)$ ( $T^{2}$ of Hotelling) for females and males of Scomberomorus brasiliensis collected off northeastern Brazil.

latitudes, whereas such marks in tropical fish are thought to be associated to environmental changes in the habitat, availability of food resources, life strategy history of the species and endogenous control (Longhurst \& Pauly, 1987).

Synchronization of band formation with gonad maturity and reproduction has been found for the king mackerel in waters off Trinidad (Sturm \& Salter, 1990) as well as for the Spanish mackerel (Scomberomorus commerson) off the eastern coast of Australia (McPherson, 1992). Band formation has also been correlated to reproductive behavior in the school mackerel (S. queenslandicus) due to its coinciding with the reproductive peak in October through January. The same is true for the spotted mackerel (S. munroi) off the eastern coast of Australia, with peak reproduction between August and October (Begg \& Sellin, 1998). Thus, the reproduction process may be related to the formation of growth bands in $S$. brasiliensis in the northeast Brazil.

The reasonable adjustment between the OR and FL resulting from the potential model (Fig. 5a-c) and the similarity between the mean observed and backcalculated lengths (Fig. 6) confirm the presupposition of proportionality between otolith size and length of the specimens (Carlander, 1981). The backcalculation method demonstrated an excellent fit to the data, with the lowest standard errors and coefficients of variation in relation to the observed data (Tables 2 and 3) for the majority of curves. Although a tendency toward underestimating mean lengths for the ages (Fig. 6), asymptotic size and overestimating the growth rate (Table 3 ) was found, the method generally demonstrated the viability of the use of growth marks on otoliths as age and growth estimators for the species in the region.

This sustains the preference for growth curves generated from observed lengths, as underestimations in the backcalculation model could cause variations in biomass estimates, for which the accuracy of growth parameters is a basic presupposition. The determination of age through growth bands is the most valuable information used in virtual population analysis, cohort analyses and catch curves (Hilborn \& Walters, 1992).

The estimated von Bertallanffy growth parameters revealed that females achieve a greater asyntotic size and

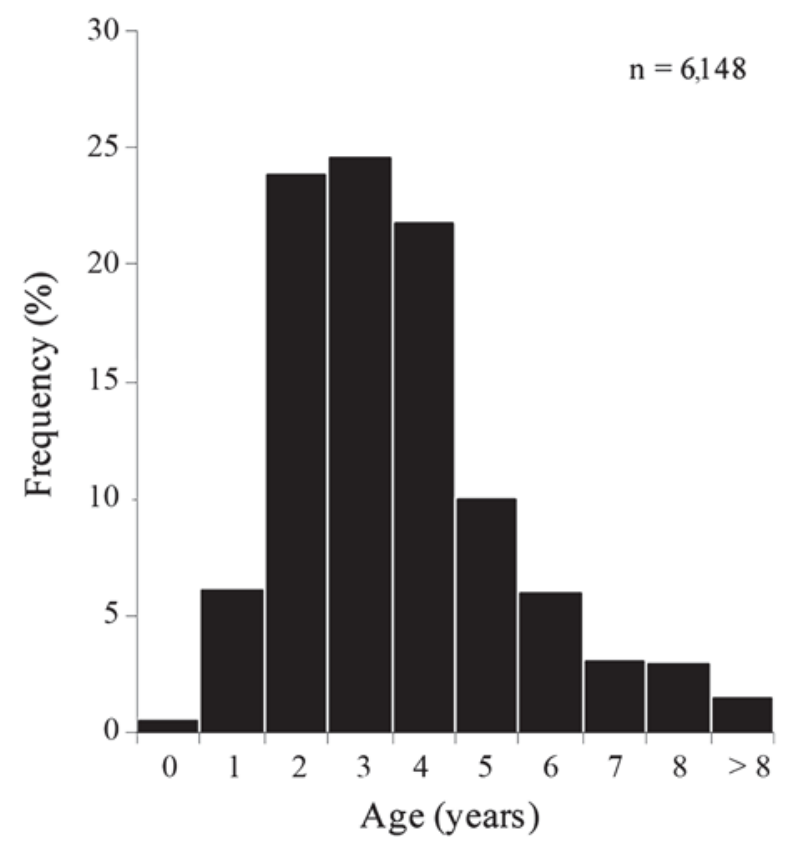

Fig. 10. Age composition for the Spanish mackerel (Scomberomorus brasiliensis) collected off northeastern Brazil. 
have a slower growth rate than males, which corroborates findings described by Nomura (1967) and Ximenes (1981). There was a significant difference between male and female growth, which is in agreement with results described by other authors, who report the difference in male and female growth patterns to be a characteristic of Scomberomorus species (Beaumariage, 1973; Powell, 1975; Sturm, 1978; Johnson et al., 1983; Fable et al., 1987; MacPherson, 1992; Schimidt et al., 1993; DeVries \& Grimes, 1997).

Differences in growth between sexes indicate that males have faster growth until approximately five years of age. Beginning at six years of age, females have larger sizes for the same age (Fig. 7). The accentuated growth rate of males in relation to females at early ages is also verified by the $z_{1}$ parameters estimated from the younger ages $\tau_{1}$ by the Schnute model, which resulted in considerably higher values for males using both the direct and backcalculated methods (Table 2). According to Gesteira \& Mesquita (1976), S. brasiliensis are ready for reproduction at $41 \mathrm{~cm}$ FL off the coast of Ceará State (3.5 years for males; 3.75 years for females). At age of first sexual maturity, females begin to have larges sizes than males for the same age and reach larger asymptotic sizes (Table 3, Fig. 7). These results suggesting that there may be a more influence of reproduction activity in females, promoting a redirection of energy to gonad maturity and reproduction, with a consequent reduction in somatic growth until the age of first sexual maturity.

Age distribution, calculated using the age-length key, indicated an accentuated catch rate of immature specimens. According to Nóbrega \& Lessa (2009a) the FL at first maturity for $S$. brasiliensis off northeastern Brazil is $42 \mathrm{~cm}$, when individuals are between 3.6 and 4 years of age, based on the estimated growth curves in the present study (considering the difference in growth between sexes). Thus, it can be concluded that approximately $58 \%$ of catches are immature specimens. Management measures that encourage an increase in the mesh size of gillnets are urgent, as is an increase usage of hand lines rather than nets in order to promote rational catches of this important fishery resource in waters off northeastern Brazil.

The growth model of Schnute, used to examine which model performed better adjustment to $S$. brasiliensis growth, in the northeastern Brazil, indicated, according the values obtained for $a$ e $b$ parameters, that the specialized von Bertalanffy model is the best to describe the species growth in the region. The collapses of important fishery stock resources in the entire world demonstrate that the methods for stock evaluation do not guarantee the resources sustainability (Schnute \& Richards, 2001). However, the search for models which minimize variance and uncertainty in data analysis of fishery biology must be permanent, in order to maximize the quality of population estimates and their exploitation levels.

The growth parameters and characteristics estimated in the present study and the age structure for $S$. brasiliensis caught by the artisanal fleet in northeastern Brazil represent an important contribution to our knowledge of the species.
The present study updates essential information for assessing the stock of this important resource, for which the last growth studies (Ximenes, 1981) in the region were carried out approximately thirty years ago.

\section{Acknowledgements}

The authors would like to thank the fishing colonies in the northeast region of Brazil; the Conselho Nacional de Desenvolvimento Científico e Tecnológico - CNPq, for the DTI (Process: 380178/99-0) and Research Productivity (Process: 301048/83-OC) grants awarded to the authors. The present study was financed by the Environment Ministry MMA, Secretary of the Inter-ministerial Commission for Ocean Resources - SECIRM, in the scope of the National Assessment Program for the Sustainable Potential of Living Resources in the Exclusive Economic Zone of Brazil - REVIZEE.

\section{Literature Cited}

Beamish, R. J. \& D. A. Founier. 1981. A method for comparing the precision of a set of age determinations. Canadian Journal of Fisheries and Aquatic Sciences, 38: 982-983.

Beaumariage, D. S. 1973. Age, growth and reprodutction of King mackerel, Scomberomorus cavalla, in Florida. Florida Marine Research Publications, 1: 1-45.

Begg, G. A. \& M. J. Sellin. 1998. Age and growth of school mackerel (Scomberomorus queenslandicus) and spotted mackerel (S. munroi) in Queensland east-coast waters with implications for stock structure. Marine Freshwater Research, 49(2): 109-120.

Campana, S. E. 2001. Accuracy, precision and quality control in age determination, including a review of the use and abuse of age validation methods. Journal of Fish Biology, 59(2): 197-242.

Carlander, K. D. 1981. Caution on the use of the regression method of back-calculating lengths from scale measurements. Fisheries, 6(1): 2-4.

Casselman, J. M. 1983. Age and growth assessment of fish from their calcified tissue-techniques and tools. NOAA Technical Report NMFS, 8: 1-17.

Cerrato, R. M. 1990. Interpretable statistical test for growth comparisons using parameters in the von Bertalanffy equation. Canadian Journal of Fisheries and Aquatic Sciences, 47(7): 1416-1426.

Collete, B. B., I. J. Russo \& A. L. Zavala-Camin. 1978. Scomberomorus brasiliensis, a new of spanish mackerel from the western atlantic. Fishery Bulletin, 76(1): 273-280.

Collete, B. B. \& C. E. Nauen. 1983. Scombrids of the words. An annotated and illustrated catalog of tunas, mackerels, bonitos and related species know to date. Vol. 2. Roma, Fao Species Catalog, 137p.

Collins, M. R., D. J. Schmidt, C. W. Waltz \& J. L. Pickney. 1989. Age and growth of king mackerel, Scomberomorus cavalla, from the Atlantic coast of the United States. Fishery Bulletin, 87(1): 49-61.

Devries, A. D. \& B. C. Grimes. 1997. Spatial and temporal variation in age and growth of King mackerel, Scomberomorus cavalla. Fishery Bulletin, 95(4): 694-708.

Fable, W. A., A. G. Johnson \& L. E. Berger. 1987. Age and growth of Spanish mackerel, Scomberomorus maculatus, from Florida and Gulf of Mexico. Fishery Bulletin, 85(4): 777-783. 
FAO. 2003. FISHSTAT PLUS 2.3: Fishery Information, Data and Statistics, time series from aquaculture (quanties and values) captures (quanties). World Wide Web Electronic Publications. www.fao.org/fi/statist/FISOFT/FISHPLUS.asp.

Francis, R. I. C. C. 1990. Back-calculation of fish lengths: a critical review. Journal of Fish Biology, 36(6): 883-902.

Gesteira, T. C. V. 1972. Sobre a reprodução e fecundidade da serra, Scomberomorus maculatus (Mitchill), no Estado do Ceará. Arquivos de Ciências do Mar, 12(2): 117-122.

Gesteira V. C. T. \& L. L. Mesquita 1976. Época de reprodução, tamanho e idade na primeira desova da cavala e da serra, na costa do estado do Ceará (Brasil). Arquivos de Ciências do Mar, 16(2): 83-86.

Hilborn, P. \& C. J. Walters. 1992. Quantitative Fisheries Stock Assessement: Choice, Dynamics and Uncertainty. New York, Chapman \& Hall, 562p.

IBAMA. 2003. Boletim Estatístico da Pesca Marítima e Estuarina (ESTATPESCA) do Nordeste do Brasil. Centro de Pesquisa e Extensão Pesqueira do Nordeste - CEPENE. Tamandaré, 187p.

Ihssen, P. E., H. E. Booke, J. M. Casselman, J. M. McGlade, N. R. Payne \& F. M. Utter. 1981. Stock identification: materials and methods. Canadian Journal of Fisheries and Aquatic Sciences, 38(12): 1838-1855.

Johnson, A. G., W. A. Fable, M. L. Willians \& L. E. Barger. 1983. Age, growth, and mortality of king mackerel, Scomberomorus cavalla, from the southeastern United States. Fishery Bulletin, 81(1): 97-106.

Julien-Flus, M. 1988. A study of growth parameters and mortality rates of Scomberomorus brasiliensis from the coastal areas of Trinidade, West Indies. Contributions to Tropical Fisheries Biology: FAO Fisheries Report 389: 385-400.

Kimura, D. K. 1980. Likelihood methods for the von Bertalanffy growth curve. Fishery Bulletin, 77(4): 765-776.

Lessa, R. P. 2006. Recursos Pesqueiros da Região Nordeste. In: Ministério do Meio Ambiente. Programa REVIZEE: Avaliação do Potencial Sustentável de Recursos Vivos na zona econômica exclusiva: Relatório Executivo/MMA, Secretaria de Qualidade Ambiental. Brasília, 280p.

Longhurst A. R. \& D. Pauly. 1987. Ecology of Tropical Oceans. San Diego, Academic Press, 407p.

Lucena, F., R. P. Lessa, R. Kobayashi \& A. Quiorato. 2004. Aspectos Biológico-Pesqueiros da Serra Scomberomorus brasiliensis capturada com rede de espera no Nordeste do Brasil. Arquivos de Ciências do Mar, 37: 93-104.

Manooch, C. S., S. P. Naughton, C. B. Grimes \& L. Trent. 1987. Age and growth of king mackerel, Scomberomorus cavalla, from the US Gulf of Mexico. Marine Fisheries Review, 49: 102-108.

McPherson, G. R. 1992. Age and growth of the narrow-barred Spanish mackerel (Scomberomorus commerson Lacépède, 1800) in northeastern Queensland waters. Australian Journal of Marine and Freshwater Research, 43: 1269-1282.

Nóbrega, M. F. 2002. Idade, crescimento e avaliação de estoque da serra Scomberomorus brasiliensis (Teleostei: Scombridae) na plataforma continental do nordeste do Brasil. MSc. Dissertation, Universidade Federal de Pernambuco, Recife, 106p.

Nóbrega, M. F. \& R. P. Lessa. 2009a. Espécies Pelágicas, Scomberomorus brasiliensis. Pp. 64-75. In: Lessa, R. P., M. F. Nobrega, J. L. Bezerra Jr., F. M. Santana, P. Duarte Neto, F. H. V. Hazin, B. P. Ferreira, F. L. Frédou, M. Diedhou \& A. Monteiro (Eds.). Dinâmica de Populações e Avaliação dos Estoques dos Recursos Pesqueiros da Região Nordeste. Fortaleza, Martins \& Cordeiro Ltda, 304p.
Nóbrega, M. F. \& R. P. Lessa. 2009b. Espécies Pelágicas, Scomberomorus cavalla. Pp. 76-89. In: Lessa, R. P., M. F. Nobrega, J. L. Bezerra Jr., F. M. Santana, P. Duarte Neto, F. H. V. Hazin, B. P. Ferreira, F. L. Frédou, M. Diedhou \& A. Monteiro (Eds.). Dinâmica de Populações e Avaliação dos Estoques dos Recursos Pesqueiros da Região Nordeste. Fortaleza, Martins \& Cordeiro Ltda, 304p.

Nomura, H. 1967. Dados biológicos sobre a serra, Scomberomorus maculatus (Mitchill), das águas cearenses. Arquivos de Ciências do Mar, 1(1): 29-39.

Nomura, H. \& M. S. S. Rodrigues. 1967. Biological notes on King mackerel, Scomberomorus cavalla (Cuvier), from northeastern Brazil. Arquivos de Ciências do Mar, 7(1): 79-85.

Pauly, D. 1987. Application of information on age and growth of fish to fishery management. Pp. 495-506. In: Summerfelt, R. C. \& G. E. Hall. (Eds.). Age and Growth of fish. Ames, Iowa State University Press, 605p.

Powell, D. 1975. Age, growth, and reproduction in Florida stocks of Spanish mackerel, Scomberomorus maculatus. Florida Marine Research Publications, 5: 1-21.

Schmidt, D. J., M. R.Collins \& D. M. Wyanski. 1993. Age, growth, maturity, and spawning of Spanish mackerel, Scomberomorus maculatus (Mitchill), from the Atlantic coast of southeastern United States. Fishery Bulletin, 91(3): 526-533.

Schnute, J. 1981. A versatile growth model with statistically stable parameters. Canadian Journal of Fisheries and Aquatic Sciences, 38(9): 1128-1140.

Schnute, J. T \& L. J. Richards. 2001. Use and abuse of fishery models. Canadian Journal of Fisheries and Aquatic Sciences, 58(1): 10-17.

Sturm, M. G. 1978. Aspects of the biology of Scomberomorus maculatus (Mitchill) in Trinidad. Journal of Fish Biology, 13(2): 155-172.

Sturm, M. G. \& P. Salter. 1990. Age, growth and reproduction of king mackerel Scomberomorus cavalla (Cuvier) in Trinidad waters. Fishery Bulletin, 88(2): 361-370.

Sutter, F. C., R. O. Willians \& M. F. Godcharles. 1991. Growth and mortality of king mackerel Scomberomorus cavalla tagged in the southeastern United States. Fishery Bulletin, 89(4): 733737.

Taylor, C. C. 1958. Cod growth and temperature. Journal du Conseil International pour l'Exploration de la Mer, 23: 366-370.

Vazzoler, A. E. A. M. 1996. Biologia da reprodução de peixes teleósteos: teoria e prática. São Paulo, EDUEM, 169p.

Ximenes, M. O. C. 1981. Idade e crescimento da serra, Scomberomorus brasiliensis no Estado do Ceará. Arquivos de Ciências do Mar, 21(1/2): 47-54.

Accepted September 4, 2009 Published December 18, 2009 